\title{
Thermogravimetric and Kinetic Analysis of Cassava Starch Based Bioplastic
}

\author{
Nanang Eko Wahyuningtiyas ${ }^{1,2}$, Heru Suryanto ${ }^{3 *}$, Eddy Rudiyanto ${ }^{4}$, Sukarni Sukarni ${ }^{5}$, and Poppy \\ Puspitasari ${ }^{6}$ \\ ${ }^{1}$ Environmentalist, Samarinda, East Borneo, Indonesia \\ 2,3,4,5,6 Department of Mechanical Engineering, Faculty of Engineering, Universitas Negeri Malang \\ heru.suryanto.ft@um.ac.id
}

\begin{abstract}
Cassava starch based bioplasticfor packaging application has great potency because of the various starchproducing plants in Indonesia.Bioplasticcan contribute to reduce the dependence on fossil fuels andpetroleumthat can solve the environmentalproblem. Thepurpose of this research is to find out the thermal decomposition and the activation energy of cassava starch based bioplastic. The methods weresynthesis bioplastic with cassava starch as main component and glycerol as plasticizer. The thermogravimetry analysis was conducted to obtain the decomposition process mechanism of bioplastic and the heating valueof bioplasticwas measured using theadiabatic bomb calorimetric. Data analysis was conducted using a fitting model approach with an acikalin method to determine the activation energy. The result of thethermogravimetricanalysis showed thatbioplasticisgraduallydecomposedto the moisture, volatilematter, fixed carbon, andash in four stages mechanism. Totally decomposition of bioplastic was $530^{\circ} \mathrm{C}$, then all of bioplastic was become the ash. The activation energy in the early and primary thermal decomposition stages are $1.27 \mathrm{~kJ} / \mathrm{mol}$ and $22.62 \mathrm{~kJ} / \mathrm{mol}$, respectively and heating valueof bioplastic is $15.16 \mathrm{MJ} / \mathrm{kg}$.
\end{abstract}

Copyright @ 2017Journal of Mechanical Engineering Science and Technology All rights reserved

Keywords: Ctivation energy, Bioplastic, Cassava starch, Decomposition, Kinetic analysis, Thermogravimetric

\section{Introduction}

The synthetic plastic is made of petroleum, coal and natural gas [1]. Plastic waste poses a risk to the human health and the environment [2]. Indonesia is one of the second largest plastic waste donors in the world after China [3]. Waste plastichas become an environmental problem around the world [4] because it takes a long time to be degraded[5][6] and take 50 years to be degraded it in nature [7]. Bioplastic can help to reduce the problem of plastic waste, because of easy to make it, abundant and affordable raw materials [8][9][10]). Itiscategorized to environmental friendly [11] and able to be degraded by the activity of microorganisms by 10 to 20 times faster than the conventional plastic resulting in carbon dioxide, methane, water, biomass, humus and other natural substances from the sources of compounds in plants, such as starch, cellulose, and lignin [5][12][13].

The number of bioplastics produced in a worldwide is less than 200.000 tons per year, a smaller number when compared to 30 million tons of petroleum-based plastic[1]. However, in 2020, the utilization of bioplastic is predicted to reach at least 10\%-30\% of the global plastics industry [14].The potential of cassava starch as bioplastic material is great since Indonesia has high cassava production, the third largest in the world [15]. The potential of cassava starch as an environmentally friendly plastic materials is very large because Indonesia is the third largest producer of cassava in the world with cassava products reached 26 million tons in 2014 [16]. The use of fossil fuels will lead to global warming [17][18] because of the fossil-made plastic release about $2900 \mathrm{~kg} / \mathrm{tons}$ of $\mathrm{CO}_{2}$ [19]. Imperfect process in the incineration also produces the harmful gases, such as $\mathrm{SO}_{2}, \mathrm{CO}$, $\mathrm{NO}_{x}, \mathrm{NO}, \mathrm{N}_{2} \mathrm{O}, \mathrm{HCl}$, and $\mathrm{HF}$ [20]. Bioplastic offers a solution in reducing the dependence on fossil fuels that have an adverse impact on the sustainable environment [2]. The incineration of bioplastic will produce $\mathrm{CO}_{2}$ [21], but lower than synthetic plastic because of the raw material (starch) is more environmental friendly. Thus, this paper explores the thermal decomposition of cassava starchbased bioplastic using the thermogravimetric and kinetic analysis 


\section{Material and method}

\section{A. Material}

The research material wasthe cassava starch from Malang, East Java, Indonesia. The glycerol in technical grade with concentration of $98 \%$ used as the plasticizer,provided by CV. Makmur Sejati, Malang, Indonesia.

\section{B. Synthesis of Bioplastic}

The synthesis of bioplastic refers to Wahyuningyas and Suryanto[6], through the process of mixing the cassava starch with glycerol.The cassava starch $5 \%$ (b/v) was mixedwithwater/aquadestof $98.5 \mathrm{ml}$,then were stirred on a magnetic stirrer at $900 \mathrm{rpm}$ for $5 \mathrm{~min}$. Next, glycerol at concentrations of $1.5 \%(\mathrm{v} / \mathrm{v})$, was added to each solution, and then the solutions were re-stirred for $5 \mathrm{~min}$ at $900 \mathrm{rpm}$. The solutions were heated on a magnetic stirrer at $80^{\circ} \mathrm{C}$ while being stirred with a magnetic stirrer at $900 \mathrm{rpm}$ for $45 \mathrm{~min}$. Each stirred solutions werecasted into a mold $88 \mathrm{mmin}$ diameter, then dried in an oven for 24 hat $70^{\circ} \mathrm{C}$, and finally placed at ambient temperature $\left(27-30^{\circ} \mathrm{C}\right)$ then kept in adesiccator.

\section{Thermogravimetry analysis}

The thermogravimetryanalysis refers to ASTME1131 [22].Thermal decomposition of bioplastic was analyzed using a thermogravimetry(Mettler Toledo TGA/DSC1 simultaneous analyzer). The 10 mg sample was heated from $30^{\circ} \mathrm{C}$ to $800^{\circ} \mathrm{C}$ with a heating rate of $10 \mathrm{oC} / \mathrm{min}$ inthepresence air with a flow rate of $50 \mathrm{~mL} / \mathrm{min}$. The thermogravimetric(TG), derivative thermogravimetric (DTG) can identify the thermal decomposition that occurs in bioplastic through the loss of weight.

\section{Kinetic Reaction}

The kinetic reaction of thermal decomposition of bioplastic can can be analyzed using the thermogravimetric method. The kinetic reaction behavior was obtained from the loss of mass towards the temperature.The activation energy (E) of bioplastic was calculated by using the kinetic calculation of Arrhenius method according to Acikalin. The following reaction scheme can illustrate the combustion of biomass:

The fraction of biomass combustion (or conversion) $\alpha$, is defined as follows:

$$
\alpha=\frac{\left(m_{o}-m_{t}\right)}{\left(m_{0}-m_{f}\right)}
$$

Where mo,mt and $\mathrm{mf}$ refer to the initial mass of biomass, the final value of time $\mathrm{t}$ and mass $\mathrm{m}$ at the end of the combustion, respectively. The degree of combustion, $\mathrm{d} \alpha / \mathrm{dt}$, is a linear function of constantly determined temperature $(\mathrm{k})$, and reaction model (sample temperature conversion function), $f(\alpha)$ :

$$
\frac{d \alpha}{d t}=\mathrm{kf}(\alpha)
$$

Replace the constant rate (k) using the Arrhenius equation, and enter the heating rate $(\beta=\mathrm{dT} / \mathrm{dt})$ in the non-isothermal case, so that equation2 will be:

$$
\frac{\mathrm{d} \alpha}{\mathrm{dt}}=\frac{\mathrm{A}}{\beta} \mathrm{e}^{\left(-\frac{\mathrm{E}}{\mathrm{RI}}\right)} \mathrm{f}(\alpha)
$$

Where $\mathrm{A}$ is the pre-exponential factor, $\mathrm{R}$ is constant gas $(8.314 \mathrm{~J} \mathrm{oK}$ mol-1), $\mathrm{E}$ is activation energy, , and $\mathrm{T}$ is aconstant temperature. Determine the value of $\mathrm{n}$ to derive equation 3 , so that equation4 will be:

$$
\frac{\mathrm{d} x}{(1-\mathrm{x}) \mathrm{n}}=\frac{\mathrm{A}}{\mathrm{A}} \mathrm{e}\left(-\frac{E}{\mathrm{EN}}\right) \mathrm{dT}
$$

Equation 4 is the expression used as the basic model in the calculation method for kinetic analyses of TG data. The activation energy and the pre-exponential factor of each active combustion stage are calculated from the corresponding slope (-E/R) and the interception of each final plot(ln (A /b)), respectively. 


\section{E. Heating value}

The heating value of bioplastic was conducted by using IKA type C2000 basic adiabatic bomb calorimetric. The sample about $0.25 \mathrm{~g}$ was heated from a temperature of $25^{\circ} \mathrm{C}$ to $270^{\circ} \mathrm{C}$ was applied for 15 min with $75 \%$ moisture and anoxygen pressure of \pm 30 bars. The heating value obtained from the process of the device is $\mathrm{J} / \mathrm{g}$ unit, by the standard ofASTM D 240. The heating value is calculated by using the measurement of the temperature of the water which increases due to heat. The bioplastic samples were wrapped in paper and burned in the bomb calorimetric. The heating value of the paper wrap without bioplastic was also measured to subtract the heat value of the paper-wrapped bioplastic sample so that the heating value of the bioplasticwas obtained from the substraction. The heating value of solid bioplastic can be determined by using bomb calorimetric.

\section{Results and discussion.}

\section{A. Thermogravimetryanalysis}

Thermogravimetric analysis is a method used to study the reaction of thermal decomposition [24] between weight change and temperature[25] which are lost due to the effect of temperature on the material. The result of thethermal analysis is in the form of a curve called a thermogram. Thermal decomposition is a process of changing the form of a sample into a simpler form [26] which is influenced by many factors such as temperature,heating rate, pressure, moisture, residence time, particle size, and material composition [27].

Thermal decomposition involves changes in the weight of the polymer [28]. The thermal decomposition of the polymer refers to an increase in temperature that either has or has not experienced any chemical changes and also serves to find out various chemical mechanisms which experience the underlying structural changes, polymer morphology effect, additive reaction path and filler interaction[29]. The mechanism of the thermal decomposition of starch based bioplastic is shown in Fig.1.

Stage 1 is the reduction weightcaused bythe release of moisture or water until $10.7 \% \mathrm{~b} / \mathrm{bthat}$ occurred at $30^{\circ}-130^{\circ} \mathrm{C}$ for $12 \mathrm{~min}$.In this stage, the very light volatile matter compounds also lost [26] and the initial stage of the thermal decomposition process occurs due to evaporation of the water[30].

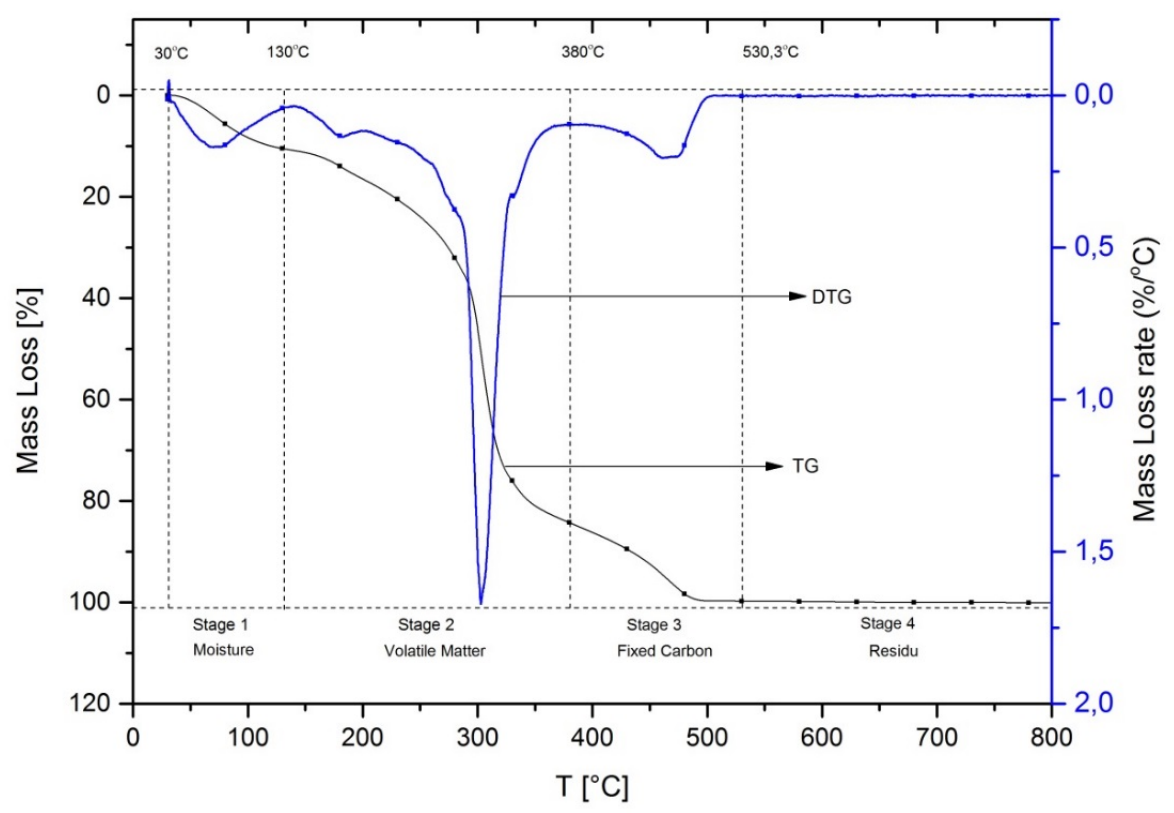

Fig. 1.TG-DTG curve of bioplastic 
Stage 2 is the process of releasing volatile matter that occurred at $130^{\circ} \mathrm{C}-380^{\circ} \mathrm{C}$ for $25 \mathrm{~min}$. This stage is the main thermal decomposition stagebecause a high level ofmaterial lost $(69.10 \% \mathrm{~b} / \mathrm{b})$ since cassava starch contains amylose particles which can form carbohydrate lipids: carbon, hydrogen, and oxygen in the volatile cassava starch [31][32]. Cassava starch starts to decomposed thermally at the temperature of $300^{\circ} \mathrm{C}$ [33]. The process of this stage triggers the rapid thermal decomposition with a large mass loss [34] and runs rapidly due to the considerable amount of oxygen.

Stage 3 is the stage after the release of volatile matter in the samples occurred at the temperature of $380^{\circ} \mathrm{C}-530^{\circ} \mathrm{C}$ for $16 \mathrm{~min}$. The fixed carbon content of bioplastic was relatively low, i.e., $20.17 \%$ (b/b). In this stage, the charcoal is flammable as it is surrounded by volatile matter and oxygen diffused on the surface of the charcoal, which burn the charcoal and volatile matter simultaneously. This stage occurs after the release of volatile matter which leaves or forms carbon [35].

Stage 4 is the last stage of the thermal decomposition process in bioplastic that occurred at $530^{\circ} \mathrm{C}-800^{\circ} \mathrm{C}$ for $23 \mathrm{~min}$. This process does not produce ash, since it has been fully decomposed in the thermal decomposition process shown in the TG-DTG graphic of the low thermal decomposition reaction, since the residue of the charcoal is surrounded by the combustion ash marked by the flat TG graph in Fig. 1, thus indicating the slowly confined mass.

\section{Acikalinmethod}

This research used a fitting model approach. The fitting model is a kinetic method which involves a single heating rate[36]. The Acikalin method is used for determining the activation energy in this study. The final equation of the Arrhenius method can be obtained by using the logarithm of Eq. 4 and makes some rearrangement as follows [37]:

$$
\ln \left(\frac{\mathrm{Ac}}{\mathrm{AT}}\right)-\mathrm{n} \ln (1-\alpha)=\ln \left(\frac{\mathrm{A}}{\rho}\right)-\frac{\mathrm{E}}{\mathrm{RT}}
$$

Where:

$$
\frac{d \alpha}{d T}=\frac{a_{T 2}-a_{T_{1}}}{T_{n}-T_{n}}
$$

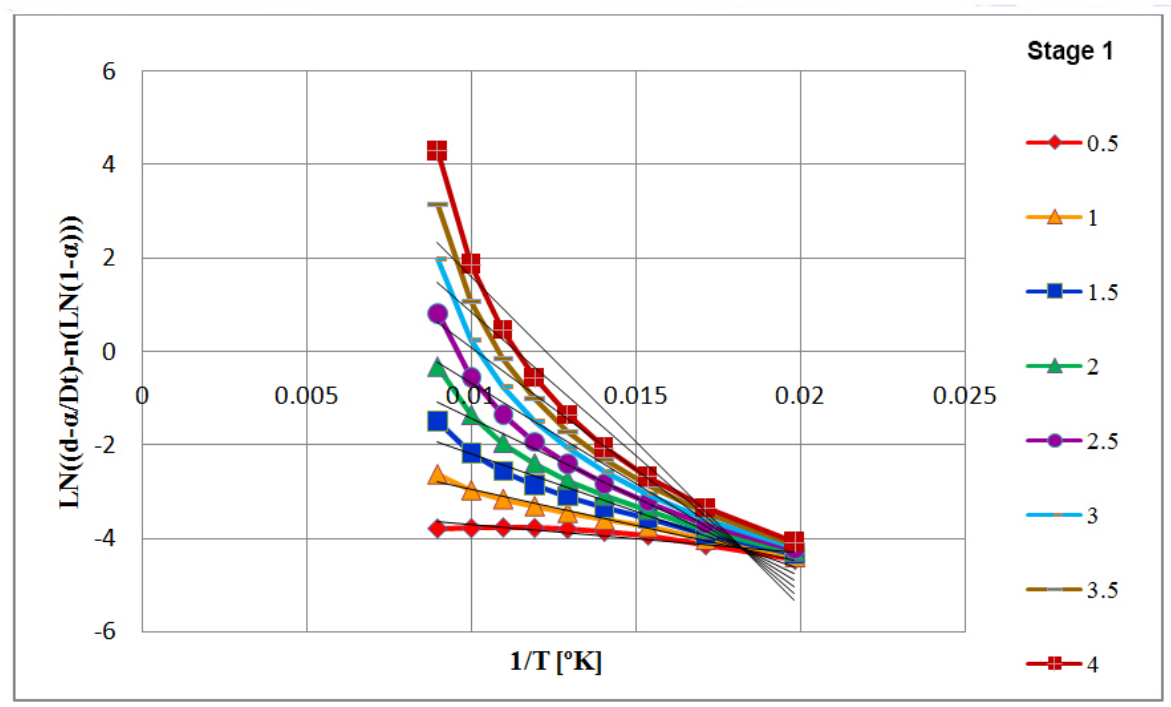

Fig. 2.Curve of stage I plot $\ln (\mathrm{d} \alpha / \mathrm{dT})-\mathrm{n} \ln (1-\alpha)$ vs $(1 / \mathrm{T})$ 


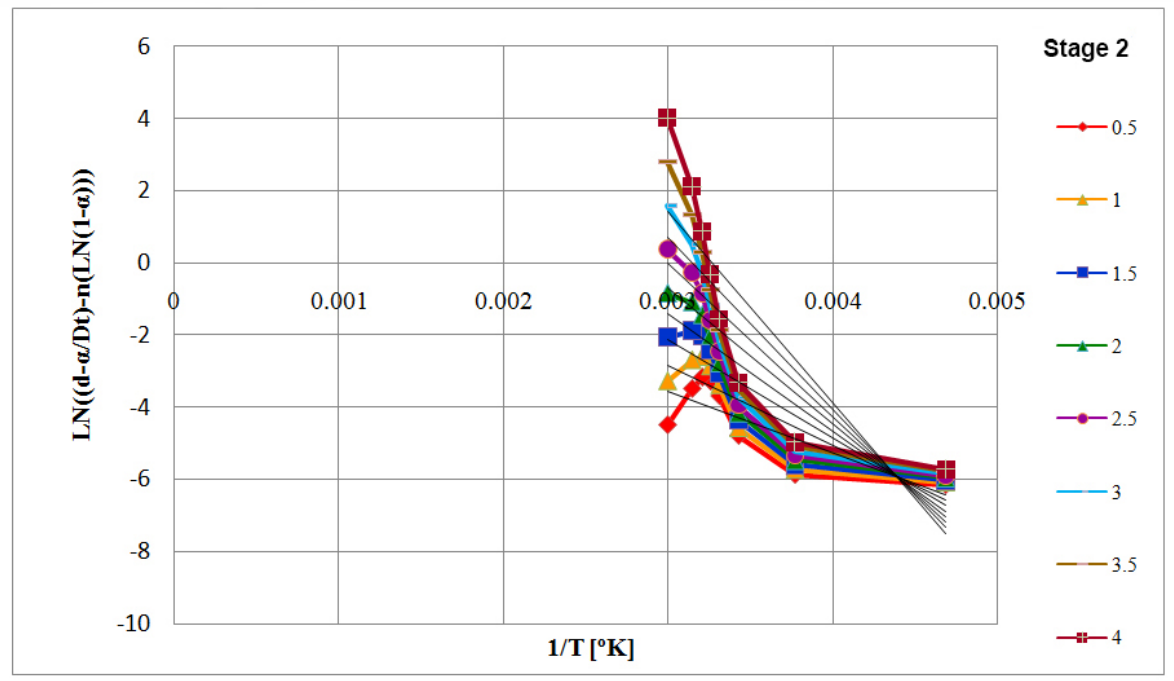

Fig. 3.Curve of stage 2 plot $\ln (\mathrm{d} \alpha / \mathrm{dT})-\mathrm{n} \ln (1-\alpha)$ vs $(1 / \mathrm{T})$

Table 1. The parameter values in Arrhenius Acikalin formula

\begin{tabular}{cccccc}
\hline Stage & $\boldsymbol{\beta} / \mathbf{o C}$ min- & E/kJ mol-1 & R2 & $\mathbf{N}$ & Plot equation \\
\hline 1 & 10 & 1.26954 & 0.982 & 1.0 & $-152.7 \mathrm{x}-1.429$ \\
\hline 2 & 10 & 22.62239 & 0.768 & 1.5 & $-2721 . \mathrm{x}+6.027$ \\
\hline
\end{tabular}

According to Eq. 5, plot $\ln (\mathrm{d} \alpha / \mathrm{dT})-\mathrm{n} \ln (1-\mathrm{a})$ vs $(1 / \mathrm{T})$ results in a straight line (slope) to determine the value of reaction order (n) (Fig. 3 and Fig. 2). In order to determine the suited $n$ value in the active combustion stage, several $n$ values were selected, the plot was drawn, and the related correlation coefficient (R2) was calculated to generate the R2 curves vs. n.

The highest R2 value ensures the most appropriate $n$ value to determine the curve of all decomposition levels studied from the $\mathrm{n}$ value and had the final plot drawn. The activation energy and the pre-exponential factor of each active combustion stage were calculated from the related slope $(-\mathrm{E} / \mathrm{R})$ and interceptions $(\ln (\mathrm{A} / \beta))$ of each final plot. The results obtained by the Arrhenius method on the final plot are shown in Table1.

$$
\mathrm{E}=\text { Slope } \mathrm{x} \mathrm{R}
$$

Kinetics is a science that discusses the rate and reaction mechanism[38]. According to Arrhenius, activation energy is the minimum energy required to start a chemical reaction (combustion). There are two ways to convert bioplastic into energy (heat), thermochemically and biochemically or biologically[17]. The conversion of bioplastic into thermochemical energy can be performed by pyrolysis, gasification, and combustion [39]. This research used combustion method. The combustion process is the process in which the combustion process occurs due to a reaction of bioplastic and oxygen to convert the solid bioplastic into the energy [38].

The activation energy determination using Flynn-Wall-Ozawa (FWO) method for cassava starch, banana starch, and potato starch was $188.0 \mathrm{~kJ} / \mathrm{mol}, 199.3 \mathrm{~kJ} / \mathrm{mol}$, and $203.60 \mathrm{~kJ} / \mathrm{mol}$, respectively.The activation energy determination usingCoats-Redfern methods for cassava starch, banana starch, and potato starch is $188.3 \mathrm{~kJ} / \mathrm{mol}, 200.2 \mathrm{~kJ} / \mathrm{mol}$, and $204.8 \mathrm{~kJ} / \mathrm{mol}$, respectively[40].It shows that the activation energy of cassava starch is low.It possibly caused by the long polymer chains and the increased polymerization, because amylose content [40] can form carbohydrate lipids: carbon, hydrogen, and oxygen in the volatile starch [41][32] in the volatile matter process. The amylose content in cassava starch is higher for $24.3 \%$ ([42] than in banana starch for $18.33 \%$ and potato starch for $16.88 \%$ [43].

The cassava starch has the lowest activation energy compared to banana and potato starch. The higher activation energy will reduce the reaction rate[44] as it will be harder to start the combustion 
reactionprocess. The low activation energy of $1.27 \mathrm{~kJ} / \mathrm{mol}$ on stage lindicates the weak bonds between volatile materials and polymers (bioplastic) [45]. In stage 2, it takes a higher energy of $22.62 \mathrm{~kJ} / \mathrm{mol}$ and a long time for $25 \mathrm{~min}$ to thermally decompose the carbohydrate particles.

Table 3 indicate that the bioplastic is easy to decompose with activation energy of 22.62 $\mathrm{kJ} / \mathrm{mol}$.This activation energy is higher than the activation energyof plastic poly-lactic acid (PLA) $(11.2 \mathrm{~kJ} / \mathrm{mol})[46][47]$ but lower than an inorganic plastic waste such as PE $(248.0 \mathrm{~kJ} / \mathrm{mol})$, PP $(183.8 \mathrm{~kJ} / \mathrm{mol})$, PS $(172.0 \mathrm{~kJ} / \mathrm{mol})$, HDPE $(233.2 \mathrm{~kJ} / \mathrm{mol})$, LDPE $(206.4 \mathrm{~kJ} / \mathrm{mol})$, PVC $(190$ $\mathrm{kJ} / \mathrm{mol}$ )[48] and the types of coallike brown coal $(39.15 \mathrm{~kJ} / \mathrm{mol})$, low coal $(73.96 \mathrm{~kJ} / \mathrm{mol})[49]$, anthracite $(40.43 \mathrm{~kJ} / \mathrm{mol})$, lignite $(28.60 \mathrm{~kJ} / \mathrm{mol})[50]$, and bituminous $(36.18 \mathrm{~kJ} / \mathrm{mol})[51]$. The higher activation energy value cause the slow and harder to initiate the combustion reaction [44][52].

The heating value

The heating valueis the energy released per unit mass of a material or when the material is fully combusted or burned. The heating valueobtained using the calorimetric bomb experiment [23]. The heating valueof bioplasticis indicated by HHV (Higher Heating Value) [53] and the someof the heating value of materials arelisted in the Table 2.

The heating value of a substance is influenced by the composition of the substance contained in the sample[60]. As shown in the thermogravimetric test result (Fig. 1), it shows that almost bioplastic is fully combusted in the volatile matter process that contains a high level of carbohydrates results the higher the heating value or energy contained [61]. The samples with low ash content are perfectspecimens because they reduce the exhaust emissions [62].

The heating value test ofbioplastic sample is $15.16 \mathrm{MJ} / \mathrm{kg}$ (Table 2). The heating value ofbioplasticis relative sama with the Polyvinyl Chloride (PVC) with HHV of $18.00 \mathrm{MJ} / \mathrm{kg}$ [54]. The heating value of bioplastic is also higher than four types of coal:bituminous coal Spanish,lignite coal Germany,anthracite Spanish,and peatSwedish with HHV of $7.55 \mathrm{MJ} / \mathrm{kg}, 9.00 \mathrm{MJ} / \mathrm{kg}, 7.97 \mathrm{MJ} / \mathrm{kg}$, and $12.66 \mathrm{MJ} / \mathrm{kg}$, respectively[56]. The heating value of bioplastic is also higher than of food waste,husk, textiles, and paper with HHV of $4.00 \mathrm{MJ} / \mathrm{kg}, 15.00 \mathrm{MJ} / \mathrm{kg}$ [55], $15.02 \mathrm{MJ} / \mathrm{kg}$ [63], 15.02 $\mathrm{MJ} / \mathrm{Kg}$ [57], respectively.

Table 2. Heating valuefrom a variety of materials

\begin{tabular}{ccc}
\hline Sample & Heating value(MJ/kg) & References \\
\hline Bioplastic cassava starch & 15.16 & This study \\
\hline Polyvinyl Chloride (PVC) & 18.00 & {$[54]$} \\
\hline Polypropylene (PP) & 46.40 & {$[54]$} \\
\hline Polyethelene (PE) & 46.30 & {$[54]$} \\
\hline Polystyrene (PS) & 41.40 & {$[54]$} \\
\hline Food waste & 4.00 & {$[55]$} \\
\hline Rice husk & 15.00 & {$[55]$} \\
\hline Textiles & 15.02 & {$[56]$} \\
\hline Bituminous coal Spanish & 7.55 & {$[56]$} \\
\hline Lignite coal Germany & 9.00 & {$[56]$} \\
\hline Anthracite Spanish & 7.97 & {$[56]$} \\
\hline Peat Swedish & 12.66 & {$[57]$} \\
\hline Corn stalks & 18.48 & {$[58]$} \\
\hline Wood & 18.42 & {$[59]$} \\
\hline Straw & 15.61 &
\end{tabular}




\section{Conclusion.}

The cassava starch based bioplasticwasthermally decomposed in four stages mechanism and, has an activation energy at the initial and main thermal decomposition stages of $1.27 \mathrm{~kJ} / \mathrm{mol}$ and 22.62 $\mathrm{kJ} / \mathrm{mol}$, respectively. Thus, theheating value of bioplastic obtained in the heat test for $15.16 \mathrm{MJ} / \mathrm{kg}$. The bioplastic can be thermally degraded as easy as the synthetic plastic.

\section{Acknowledgements}

Greatly appreciate to the Ministry of Research and Technology and Higher Education, Republic Indonesia through PUPT program with contract no: 3.4.8/UN.32.14/LT/2017

\section{References}

[1] Reddy R. Laxmana, Reddy V Sanjeevani, and Gupta G Anusha, "Study of Bio-plastics As Green \& Sustainable Alternative to Plastics," Int. J. Emerg. Technol. Adv. Eng., vol. 3, no. 5, pp. 82-89, 2013.

[2] Kaewphan Narissara and Gheewala Shabbir H, "Greenhouse gas evaluation and market opportunity of bioplastic bags from Cassava in Thailand," J. Sustain. Energy Environ., vol. 4, pp. 15-19, 2013.

[3] J. R. Jambeck, R. Geyer, C. Wilcox, T. R. Siegler, M. Perryman, A. Andrady, R. Narayan, and K. Lavender, "Plastic waste inputs from land into the ocean," Science (80-. )., vol. 347, no. 6223, pp. 768 770, 2015.

[4] Gill Mukti, "Bioplastic: A Better Alternative To Plastics," J. Impact, vol. 2, no. 8, pp. 115-120, 2014.

[5] L. Averous, "Biodegradable Multiphase Systems Based on Plasticized Starch: A Review," Macromol. Sci. Part C Polym. Rev., vol. 44, no. 3, pp. 231-274, 2004.

[6] Wahyuningtiyas Nanang Eko and Suryanto Heru, "Analysis of Biodegradation of Bioplastics Made of Cassava Starch,” J. Mech. Eng. Sci. Technol., vol. 1, no. 1, pp. 41-54, 2017.

[7] Webb Hayden K., A. Jaimys, Crawford Russell J., and Ivanova Elena P., "Plastic Degradation and its Environmental Implications with Special Reference to Poly(ethylene terephthalate)," Polymers (Basel)., vol. 5, no. 1, pp. 1-18, 2013.

[8] S. Domenek, P. Feuilloley, J. Gratraud, H. Morel Marie, and S. Guilbert, "Biodegradability of wheat gluten based bioplastics," Chemosphere, vol. 54, no. 4, pp. 551-559, 2004.

[9] Y. Song and Q. Zheng, "Preparation and properties of thermo-molded bioplastics of glutenin-rich fraction," Cereal Sci., vol. 48, no. 1, pp. 77-82, 2008.

[10] G. J. Gutierrez, P. Partal, M. G. M., and C. Gallegos, "Effect of processing on the viscoelastic, tensile and optical properties of albumen/starch-based bioplastics," Carbohydr. Polym., vol. 84, no. 1, pp. 308315, 2011.

[11] J. M. Sakra, "Biodegradable Pati Kentang Sebagai Bahan Plastik,” Jaringan Penelitian KTI, 2015. .

[12] Berkesch Shellie, "Biodegradable Polymers : A Rebirth of Plastic Shellie Berkesch," 2005.

[13] V. G. L. Souza and F. A. Luisa, "Nanoparticles in food packaging: Biodegradability and potential migration to food-A review," Food Packag. Shelf Life, vol. 8, pp. 63-70, 2016.

[14]Fernyhough Alan and Markotsis Martin, "Long Biofibers and Engineered Pulps for High Performance Bioplastics and Biocomposites," in Handbook of Bioplastics and Biocomposites Engineering Applications, Pilla Srik., USA: Wiley, 2011, p. 604.

[15] Setyawaty Rety, Katayama-Hirayama Keiko, Kaneko Hidehiro, and Hirayama Kimiaki, "Current Tapioca Starch Wastewater TSW Management in Indonesia,” World Appl. Sci. J., vol. 14, no. 5, pp. 658-665, 2011.

[16] Julianto, “Tabloid Sinar Tani: Produksi Singkong Nasional,” 2014.

[17] Huang Y. F., Chiueh P. T., Kuan W. H., and Lo S. L., "Pyrolysis kinetics of biomass from product information," Appl. Energy, vol. 110, pp. 1-8, 2013.

[18] CNN, "KTT Iklim Sepakati Pengurangan Bahan Bakar Fosil,” 2015. .

[19] Yuki Sakamoto, "Life Cycle Assessment of Biodegradable Plastics," J. Shanghai Jiaotong Univ., vol. 17, no. 3, pp. 327-329, 2012.

[20] Suksankraisorn K., S. Patumsawa, Vallikul P., Fungtammasan B., and Accary A., "Co-Combustion of Municipal Solid Waste and Thai Lignite in a Fluidized Bed," Energy Convers. Manag., vol. 45, no. 6, pp. 947-962, 2004.

[21] Sparajcar Masa, Horvat Petra, and Krzan Andrej, Biopolymers And Bioplastics. 2012.

[22] ASTM E 1131, Compositional Analysis by Thermogravimetry, vol. 5. United States, 2004. 
[23] ASTM D 240, Standard Test Method for Heat of Combustion of Liquid Hydrocarbon Fuels by Bomb Calorimeter. United States, 2004.

[24] Y. Zhaosheng, Xiaoqian Ma, and L. Ao, "Kinetic studies on catalytic combustion of rice and wheat straw under air- and oxygen-enriched atmospheres, by using thermogravimetric analysis," Biomass and Bioenergy, vol. 32, no. 11, pp. 1046-1055, 2008.

[25] Ahmad Zuraida, Anuar Hazleen, and Yusof Yusliza, “The Study of Biodegradable Thermoplastics Sago Starch," Key Eng. Mater., vol. 471-472, pp. 397-402, 2011.

[26] Sukarni, Sudjito, HAMIDI Nurkholis, YANUHAR Uun, and WARDANA I.N.G, "Thermogravimetric kinetic analysis of Nannochloropsis oculata combustion in air atmosphere," Front. Energy, p. 9, 2015.

[27] Slopiecka Katarzyna, Bartocci Pietro, and Fantozzi Francesco, "Thermogravimetric analysis and kinetic study of poplar wood pyrolysis," Appl. Energy, vol. 97, pp. 491-497, 2012.

[28]Zeus, “Thermal Degradation of Plastics," Zeus Industrial Products, pp. 1-8, 2005.

[29] Pielichowski Krzysztof and Njuguna James, Thermal degradation of polymeric materials, vol. 1994, no. 3. 2005.

[30] Yeum Jeong Hyun, Park Jae Hyeung, and Choi Jae Young, "Polymer / Montmorillonite / Silver Prepared by In-Situ Polymerization and Electrospraying Technique," Intech, 2006.

[31]Li Jeng Yune and Yeh An I., "Relationships between thermal, rheological characteristics and swelling power for various starches," J. Food Eng., vol. 50, no. 3, pp. 141-148, 2001.

[32] Raabe Joabel, Fonseca Alessandra De Souza, Bufalino Lina, Ribeiro Caue, Martins Maria Alice, J. M. Marconcini, Mendes Lourival M, and Tonoli Gustavo Henrique Denzin, "Biocomposite of Cassava Starch Reinforced with Cellulose Pulp Fibers Modified with Deposition of Silica ( $\mathrm{SiO} 2$ ) Nanoparticles," J. Nanomater., vol. 2015, pp. 1-9, 2015.

[33] Shanks Robert and Kong Ing, "Thermoplastic Starch," in Thermoplastic Elastomers, Sonbati Adel El, Ed. Australia: InTech Published, 2012, p. 23.

[34] Marras Sotirios I, Kladi Konstantina P, and Tsivintzelis Ioannis, "Biodegradable polymer nanocomposites: The role of nanoclays on the thermomechanical characteristics and the electrospun fibrous structure," Biomaterialia, vol. 4, pp. 756-765, 200.

[35] Azevedo Viviane M, Dias Marali V, Borges Soraia V, Letícia Ana, Costa R, and Keven Eric, "Food Hydrocolloids Development of whey protein isolate bio-nanocomposites : Effect of montmorillonite and citric acid on structural , thermal , morphological and mechanical properties," Food Hydrocoll., vol. 48, pp. 179-188, 2015.

[36] Yang Qing, Wu Shubin, Lou Rui, and Lv Gaojin, "Analysis of Wheat Straw Lignin by Thermogravimetry and Pyrolysis-Gas Chromatography Mass SpectrometryAnalysis of wheat straw lignin by thermogravimetry and pyrolysis-gas chromatography/mass spectrometry," J. Anal. Appl. Pyrolysis, vol. 87, no. 1, pp. 65-69, 2010.

[37] Acikalin Korkut, "Pyrolytic Characteristics and Kinetics of Pistachio Shell by Thermogravimetric Analysis,” J. Therm. Anal. Calorim., vol. 109, no. 1, pp. 227-235, 2012.

[38] Vhathvathai Navirin, "Thermochemical Behaviour and Syngas Production from Co-gasification of Biomass and Coal Blends," Australia, 2013.

[39] Sharma Abhishek, Pareek Vishnu, and Zhang Dongke, "Biomass pyrolysis-A review of modelling, process parameters and catalytic studies,” Renew. Sustain. Energy Rev., vol. 50, pp. 1081-1096, 2015.

[40] Gõmez Posidia Pineda, Angel-Gil Natalia C., Valencia-Muñoz Carolina, Rosales-Rivera Andres, and Rodríguez-García Mario E., "Thermal Degradation of Starch Sources Green Banana, Potato, Cassava, and Corn," Starch/Staerke, vol. 66, no. 7-8, pp. 691-699, 2014.

[41] Li Jeng-Yune and Yeh An-I, "Relationships between thermal, rheological characteristics and swelling power for various starches," Food Eng., vol. 50, no. 3, pp. 141-148, 2001.

[42] Oladunmoye Olufunmilola O, Aworh Ogugua C, Maziya-Dixon Bussie, Erukainure Ochuko L, and Elemo Gloria N, "Chemical and Functional Properties of Cassava Starch, Durum Wheat Semolina Flour, and their Blends," Food Sci. Nutr., vol. 2, no. 2, pp. 132-8, 2014.

[43] Yadav Ritika B., Kumar Neeraj, Yadav Baljeet S., and Yildiz Fatih, "Characterization of Banana, Potato, and Rice Starch Blends for their Physicochemical and Pasting Properties," Cogent Food Agric., vol. 2, no. 1, p. 1127873, 2016.

[44] Ounas A., Aboulkas A., El harfi K., Bacaoui A., and Yaacoubi A., "Pyrolysis of Olive Residue and Sugar Cane Bagasse Non-Isothermal Thermogravimetric Kinetic Analysis," Bioresour. Technol., vol. 102, no. 24, pp. 11234-11238, 2011. 
[45] Chaudhary Ratiram Gomaji, A. Parvej, Gandhare Nilesh V., Tanna Jay A., and Juneja Harjeet D., "Thermal Decomposition Kinetics of Some Transition Metal Coordination Polymers of Fumaroyl Bis (Paramethoxyphenylcarbamide) using DTGDTA Techniques," Arab. J. Chem., 2015.

[46] Lehermeier Hans J., Dorgan John R., and Way J. Douglas, "Gas permeation properties of poly(lactic acid)," J. Memb. Sci., vol. 190, no. 2, pp. 243-251, 2001.

[47] Jamshidian Majid, Tehrany Elmira Arab, Imran Muhammad, Jacquot Muriel, and Desobry Stéphane, "Poly-Lactic Acid: Production, applications, nanocomposites, and release studies," Compr. Rev. Food Sci. Food Saf., vol. 9, no. 5, pp. 552-571, 2010.

[48] Sorum Lasr, Characterisation of MSW for Combustion Systems. Sintef Energy research, 2001.

[49] Lyrshchikov S Yu, Strizhak P A, and Shevyrev S A, "Thermokinetic Parameters of Decomposition of Coal and Coal Processing Waste," 2016.

[50] Korotkikh Alexander G, Slyusarskiy Konstantin V, and Sorokin Ivan V, "Coal Char Oxidation Kinetics in Air Medium,” in Matec, 2017, vol. 1020, pp. 1-5.

[51] Hicyilmaz C and Aitun N E, "Comparison of the Combustion Characteristics of Three Different Fossil Fuels from Turkey,” in IMCET, 2003, no. 1988, pp. 401-406.

[52] Ma Zhongqing, Chen Dengyu, Gu Jie, Bao Binfu, and Zhang Qisheng, "Determination of pyrolysis characteristics and kinetics of palm kernel shell using TGA-FTIR and model-free integral methods," Energy Convers. Manag., vol. 89, pp. 251-259, 2015.

[53] Owens Eleanor and Cooley Sarah, "Calorific Value of Irish Woodfuels," pp. 1-8, 2013.

[54] Coterlic Liviu, "Thermal Properties of Solid Waste Materials," in Advanced Composite Materials Engineering, 2014, vol. 1, no. October, pp. 46-50.

[55] Balat M., "Mechanisms of Thermochemical Biomass Conversion Processes. Part 3: Reactions of Liquefaction," Energy Sources, Part A Recover. Util. Environ. Eff., vol. 30, no. 7, pp. 649-659, 2008.

[56] International Energi Agency, Coal Information. 2011.

[57]Dong Trang T T and K. L. Byeong, "Analysis of Potential RDF Resources from Solid Waste and Their Energy Values in the Largest Industrial City of Korea,” Waste Manag., vol. 29, no. 5, pp. 1725-1731, 2009.

[58]T. T. T. Dong and B.-K. Lee, "Analysis of potential RDF resources from solid waste and their energy values in the largest industrial city of Korea," Waste Manag., vol. 29, no. 5, pp. 1725-1731, May 2009.

[59] K. M. N. Islam and K. M. Nazmul, "Municipal Solid Waste to Energy Generation in Bangladesh: Possible Scenarios to Generate Renewable Electricity in Dhaka and Chittagong City," J. Renew. Energy, vol. 2016, pp. 1-16, Sep. 2016.

[60] Protasio Thiago de Paula, Bufalino Lina, Tonoli Gustavo Henrique Denzin, Junior Mario Guimaraes, Trugilho Paula Fernando, and Mendes Lourival Marin, "Brazilian Lignocellulosic Wastes for Bioenergy Production: Characterization and Comparison with Fossil Fuels," Bioresources, vol. 8, no. 1, pp. 11661185, 2013.

[61] Gravalos Ioannis, Kateris Dimitrios, Xyradakis Panagiotis, Gialamas Theodoros, Loutridis Spiros, Augousti Augoustinos, Georgiades Anastasios, and Z. Tsiropoulos, "A Study on Calorific Energy Values of Biomass Residue Pellets for Heating PurposesA study on calorific energy values of biomass residue pellets for heating purposes," 2010.

[62] Obernberger Ingwald, Brunner Thomas, and Bärnthaler Georg, "Chemical Properties of Solid Biofuels-Significance and Impact," Biomass and Bioenergy, vol. 30, no. 11, pp. 973-982, 2006.

[63] Islam K. M. Nazmul, "Municipal Solid Waste to Energy Generation in Bangladesh : Possible Scenarios to Generate Renewable Electricity in Dhaka and Chittagong City," J. Renew. Energy, vol. 2016, pp. 116, 2016. 